\title{
O książce, która nie chciała być biografią. Autokomentarz
}

Jerzy Kandziora

TEKSTY DRUGIE 2019, NR 1, S. 270-282

DOI: 10.18318/td.2019.1.18 | ORCID: 0000-0001-6502-7464

1.

Nie zamierzam snuć teoretycznych rozważań na temat biografistyki ani też jej dzisiejszych wcieleń. Jednakże siłą rzeczy to, co w mojej indywidualnej drodze wydarzyło się podczas pracy nad książką Poeta w labiryncie historii. Studia o pisarskich rolach Jerzego Ficowskiego ${ }^{1}$, a co nazwałbym dość przypadkowym wejściem na grunt biografistyki, każe mi widzieć całą płynność granic samego pojęcia. Istnieją bowiem rodzaje wrażliwości artystycznej, sposoby krystalizacji sztuki (poezji), procesy osmozy między biografią autora i jego dziełem towarzyszące twórczości, dla opisu których absolutnie niezbędne jest bycie blisko „fabuły życia”, poznawczych zaangażowań twórcy. Nie oznacza to jednak, że wchodzimy na teren biografistyki, że wybieramy ten tradycyjny gatunek pisarstwa naukowego.

Fakt, że z mojego pisania o Ficowskim powstała książka, którą niektórzy skłonni są traktować jako biografię pisarza, postrzegam jako rzecz tyleż zrozumiałą,

Jerzy Kandziora dr hab., pracownik IBL PAN, członek Pracowni Poetyki Teoretycznej i Semiotyki Kultury, badacz literatury współczesnej, bibliograf, edytor, opublikował m.in. książki Ocalony w gmachu wiersza. O poezji Stanisława Barańczaka (2007) i Poeta w labiryncie historii. Studia o pisarskich rolach Jerzego Ficowskiego (2017). Kontakt: jerzy.kandziora@ibl.waw.pl.

1 J. Kandziora Poeta w labiryncie historii. Studia o pisarskich rolach/erzego Ficowskiego, Fundacja Terytoria Książki, Gdańsk 2017. 
co niemającą związku z moimi intencjami, sposobem myślenia o Ficowskim. Znajomy profesor, który zaprosił mnie na swą uczelnię, abym w ramach zajęć $\mathrm{z}$ edytorstwa naukowego opowiedział jego studentom o pracy nad książką, jednej rzeczy nie mógł mi darować, a mianowicie, że w łatwy sposób nie odnalazł w książce daty urodzin i daty śmierci Ficowskiego. Domyślam się, że lektura tej książki, być może rozpoczęta bez a priori powziętej klasyfikacji gatunkowej, zakończyła się zdefiniowaniem jej jako biografii i, po zakończeniu lektury, wymierzeniem w nią oczekiwań, jakie kategoria biografii implikuje $\mathrm{w}$ tradycyjnej genologii. Ten sam, jak sądzę, tradycyjny wzorzec, tym razem biografii rozumianej jako kompletny zapis czyjegoś życia, kazał jednemu z gości mojego spotkania promocyjnego sformułować zarzut braku w książce rozdziału o Ficowskim jako autorze studium o Witoldzie Wojtkiewiczu.

\section{2.}

Istnieje, jak sądzę, grupa badaczy bliskich mi pokoleniowo, których szczególnie interesuje silny rezonans historii w literaturze. Doświadczenie odsłaniania tego, co nieoficjalne, z oficjalności wyparte i w niej zakazane było ich pokoleniowym przeżyciem w ostatnich dekadach PRL-u. Urodzony rok po śmierci Stalina należę do owej grupy i myślę, że książka o Ficowskim mieści się w tej sekwencji moich prac, na którą złożyły się: Zmęczeni fabuła - rzecz o zachodzącym w polskiej prozie lat 70. XX wieku odwrocie od fikcji ku zapisowi osobistemu, tom bibliograficzny Bez cenzury 1976-1989. Literatura - ruch wydawniczy - teatr (współautorstwo), który rejestrował teksty zakazane w oficjalnym obiegu wydawniczym w Polsce, a także monografia twórczości poetyckiej Stanisława Barańczaka Ocalony w gmachu wiersza. Zjawiska i autorzy, którymi się zajmowałem (w pierwszej książce byli to Konwicki, Kazimierz Brandys i Woroszylski), istniały w sferach wzmożonego ciśnienia historii najnowszej, w dużej mierze w obiegach alternatywnych, gdyż nie akceptowała ich cenzura, a dzieła te i twórcy poszukiwali nowego języka literatury, silnie odnosząc się do społecznych kontekstów. Pisanie o nich było przygodą, próbą opisu tej interakcji,jaka zachodzi między dziełem, tekstem literackim, a doświadczaną historią.

Jerzy Ficowski dla badacza zainteresowanego tego rodzaju interakcjami literatury i historii jest twórcą szczególnie ciekawym. Doświadczenie historyczne trwało raz mocniej, raz słabiej w jego poezji, przemilczane, to znów wybijające się na powierzchnię, a od pewnego momentu, od połowy lat 70., pisarz zaczął sam ten proces historii niewypowiedzianej czynić tematem poezji i autokomentarzy. Milczenie stało się ważnym znakiem czy figurą 
w jego wierszach. Ficowski był jednak medium historii najnowszej niejako w dwójnasób. Bo poza poezją, w swej pisarskiej aktywności, zjawiał się w różnych przestrzeniach polskiej kultury, budował jej nowe enklawy (jak choćby cyganologię), funkcjonował w sferach kultury popularnej, otwarł w Polsce oparte na źródłach i korespondencji z polskimi Żydami badania schulzologiczne. Był w swych działaniach często samotnym prekursorem. Otwierając te pola twórczej aktywności, odległe od pewnej ortodoksji peerelowskiej, poszerzał sfery wolności, testował granice systemu.

Mnie osobiście perspektywa opisu Ficowskiego jako medium swojego czasu w obu powyższych aspektach wydała się bardzo potrzebna i pociągająca po okresie prac ściśle bibliograficznych i potem pracy nad książką o poezji Barańczaka, w trakcie której zasadniczo poruszałem się w orbicie wierszy. Obiecywała wielość perspektyw interpretacyjnych, różnorodność przedmiotu badań, swego rodzaju stereometrię w opisie fenomenu, jakim Ficowski pozostawał w latach PRL. Autor ten tkwił w mojej pamięci od dawna jako pisarz osobny, niesformatowany, zarówno w sensie swojej myślowej niezależności, jak i niezwykłości jego domen twórczych. Odczucie to miało nawet swój wizualny ekwiwalent jako wczesna pamięć okładek jego książek - Regionów wielkiej herezji, o formacie niedużym, prawie kwadratowym, w pewnym sensie nowoczesnym (w tej serii graficznej Wydawnictwo Literackie wydało także kilka innych książek, m.in. Andrzeja Banacha), czy Cyganów na polskich drogach, z zapadającym w pamięć zdjęciem taboru cygańskiego o wschodzie słońca na obwolucie.

Wczesnego Ficowskiego-poety nie czytałem regularnie. Przypomniał mi o sobie w stanie wojennym książką Gryps i Errata, osobliwym dwu-tomikiem wierszy, który ukazał się w WL w 1982 roku i był złożeniem w oficjalnym obiegu wcześniejszych edycji niecenzurowanych: Grypsu w NOW-ej w 1979 oraz Erraty w londyńskiej Librze w 1981 roku. Oczywiście oba cykle w tym łącznym oficjalnym wydaniu zostały ocenzurowane, niektóre wiersze wypadły całkowicie, z niektórych usunięto dedykacje czy inne fragmenty. Ale mimo wszystko był to tomik poruszający, który robił wielkie wrażenie, a w liryce Ficowskiego był wyrazistym odnowieniem dykcji. Poza tym, czytany w czasie przygnębienia związanego ze stanem wojennym, dawał ogromne pocieszenie i ukazywał dojrzały dyskurs o historii, którego tak wtedy potrzebowałem. Dlatego też w jakimś stanie intensywnego pobudzenia napisałem recenzję Grypsu i Erraty dla „Tygodnika Powszechnego”. Cenzura oczywiście zdjęła ją w całości z łamów pisma. Ten tekst jednak doprowadził do mojego spotkania z Ficowskim. Opublikowało go wkrótce pozacenzuralne „Bez Debitu” 
w Poznaniu, a ja, będąc w Warszawie, zaszedłem do autora na plac Inwalidów i ofiarowałem mu numer $\mathrm{z}$ recenzją.

Ficowski w historycznych kontekstach ponownie dał mi o sobie znać w wolnej już Polsce, w 1999 roku, zapraszając na międzynarodowe seminarium Ośrodka Pogranicze Sztuk, Kultur i Narodów w Sejnach jemu poświęcone. Ośrodek realizował już wówczas szeroki program edycji i reedycji dzieł poety i wyróżnił go wtedy tytułem Człowieka Pogranicza. Podczas dyskusji na seminarium starły się dwie szkoły myślenia o poezji Ficowskiego. Piotr Sommer przedstawił sugestywny referat, prezentujący systematykę językowych i słowotwórczych przetworzeń w poezji Ficowskiego. Przy okazji niejako bohaterem negatywnym uczynił mój tekst o Grypsie i Erracie, już wówczas zamierzchły, emocjonalnie osadzony w stanie wojennym, wszelako bliski Ficowskiemu i dlatego na sesję przeze mnie przywieziony. Odczytałem go, choć miałem w zanadrzu rzecz nowszą. „Nie tak winno się pisać o poezji Ficowskiego” taki był mniej więcej sens komentarza Sommera, kiedy rozpoczynał swoje wystąpienie. I rzeczywiście otwierało ono wówczas, w wymiarze krytycznoliterackim, nową, wolną od historycznych cieni fazę czytania Ficowskiego.

3.

Ale nie potrzeba repliki stała u źródeł mojej książki o Ficowskim w labiryncie historii. Jeśli decydujemy się na wybór przedmiotu badań, wyznaczamy sobie nowe zadanie, to wybieramy obszary jakoś niewygasłe w naszym odbiorze, których pole grawitacyjne odczuwamy i które domaga się wykresu w postaci książki naukowej. Rozpocząłem ją od tekstów ściśle interpretacyjnych, skupionych na poezji. Po dokumenty, archiwalia, zacząłem sięgać nieco później, kiedy gotowe były trzy początkowe szkice: o poetyckiej narracji historycznej mediującej z wiekiem zaborów i epoką międzypowstaniową, o cyklu zagładowym Odczytanie popiołów i o wątkach AK-owskich. Archiwalia stopniowo zaczęły wpływać na refleksje o poezji. Prowadziłem regularne kwerendy w Ossolineum w zbiorze korespondencji poety, wspierane funduszami z grantu, kwerendy w Bibliotece Uniwersytetu Warszawskiego, oraz krótsze rozpoznania w Muzeum Literatury im. Adama Mickiewicza, w archiwum ZAiKS i Narodowym Archiwum Cyfrowym. Dość wcześnie pojedyncze dokumenty zaczęły pomagać w zrozumieniu wierszy, np. analizowanego w rozdziale o tropach AK-owskich ekspiacyjnego tekstu Defilada, z ukrytą w nim postacią Zbigniewa Manysia, przyjaciela poety, AK-owca zastrzelonego tuż po wojnie w potyczce oddziału z UB. 
W pewnym momencie, $\mathrm{w}$ miarę postępu prac, w bloku tekstów interpretacyjnych nastąpiło ważne dla książki odwrócenie perspektywy. Pisane studia przestały traktować jedynie o historii uwewnętrznionej w poezji, a poczęły opisywać sytuację p o e zj i w his to rii. Historia zaczęła objawiać się nie jako przedmiot lirycznego opisu, a jako czynnik działający poza wierszami, i tematem refleksji stało się przetrwanie poezji w nowych odsłonach historii. Trzy dalsze rozdziały: o pierwiastkach socjalistycznych we wczesnych utworach Ficowskiego, a w istocie - o osunięciu się tej poezji, po udanym debiucie Otowiani żotnierze, w jałowość estetyki socrealizmu, o wierszach z cyklów Przepowiednie i Pojutrznia pisanych w stanie wojennym 1981/1982, oraz o wpływie Tuwima-czarnoksiężnika na Ficowskiego, coraz bardziej liczą się z kontekstami historii i budują hipotezy psychologiczne. Jasne, że ciągle było to pisanie o tekście poetyckim, ale takie pisanie, które wpuszcza do analiz szum ulicy, słowa trybuny politycznej, polemiki prasowe, zagrożenia egzystencjalne związane z AK-owskim rodowodem, presję kodeksów moralnych społecznego oporu, zatem, krótko rzecz ujmując, zajmuje się także kontekstami uprawiania poezji.

Kontakt z archiwaliami otworzył więc przestrzeń konceptualizacji już nie tylko w sferze interpretacji, ale także wyborów artystycznych, emocjonalnych, pozwalał uruchomić ową kategorię „ról pisarskich”, która stała się dla książki kluczowa. Była dla mnie ważna, ponieważ była formułą otwartą, pozwalała przemieszczać się stale między tekstem dzieła a tekstem biografii, nie izolowała żadnej z tych przestrzeni, a przeciwnie, skłaniała do równoczesnej obserwacji pisarza działającego w realiach społecznych i - gdzieś znacznie głębiej - rodzącego się w tym czasie dzieła. Na tym etapie miał dla mnie duże znaczenie kontakt z zespołem niepublikowanych zapisków dziennikowych poety, dostępnych w formie kart maszynopisowych, sporządzanych bardzo wyrywkowo, a później niekontynuowanych.

Okazały się one ważne dla poszerzenia wiedzy m.in. o kontaktach Ficowskiego z Tuwimem. W pewnym sensie zapisy te odkrywały drugą twarz Ficowskiego w relacji z autorem Kwiatów polskich. Kult dla skamandryty, powojennego protektora Ficowskiego, dzielącego z nim fascynacje cyganologiczne (krótko przed śmiercią Tuwim polecił książkę Cyganie polscy redaktorowi Państwowego Instytutu Wydawniczego), ale też poetyckiego mistrza, którego przedwojenna poezja wyraźnie odciska się na debiucie Ficowskiego Ołowiani żotnierze, który wreszcie, należąc po wojnie do faworytów władzy komunistycznej, dawał Ficowskiemu, poecie o rodowodzie AK-owskim, swoje wsparcie w czasach publicystycznych samosądów i działań bezpieki, otóż kult ów w zapisach dziennikowych Ficowskiego współistnieje z głębokim urazem. 
Tuwim jawi się w nich także jako kusiciel, hipnotyzer, fałszywy doradca, w ostatnich latach swego życia, w apogeum stalinizmu swoimi pochwałami utwierdzający Ficowskiego w kompromisach artystycznych, których owocem były wiersze z tomików Zwierzenia (1952) i Po polsku (1955).

Do grupy archiwaliów związanych z Tuwimem należał także zbiór listów do niego Jerzego Ficowskiego w zbiorach Muzeum Literatury. Uzupełniony o listy do Ficowskiego opublikowane przez Tadeusza Januszewskiego w książce korespondencji Tuwima Listy do przyjaciót-pisarzy, pozwolił na swoistą psychosocjologiczną rekonstrukcję powodów dramatu poetki Papuszy. Wyniknął on z pozyskania Papuszy przez Ficowskiego (i pośrednio przez Tuwima) dla realizacji planów pisarskich, co starszyzna cygańska, po publikacji wywiadu Tuwima z Ficowskim, a potem książki Cyganie polscy, uznała za dowód zdrady Papuszy. Zagrożona drakońską karą, zmuszona została do ucieczki wraz z najbliższymi na południe Polski. Szkic w mojej książce na ten temat najsilniej chyba oddala się od materii ściśle filologicznej, rekonstruując (nie bez pewnego ryzyka) hipotetyczne motywy działań obu poetów, ich uwikłanie w czas historyczny i we własne emocje. Nie sposób było inaczej napisać tego szkicu. Dialog epistolarny Ficowskiego i Tuwima był zapisem fascynującym, wyprowadzał daleko poza ich twórczość, nawet poza sprawę Papuszy, ku problematyce trwania nieoswojonych enklaw kulturowych w warunkach rozszerzającego się wpływu ideologii stalinowskiej.

Historia Papuszy była tym wydarzeniem w biografii Ficowskiego, które stało się potem jedną z „opowieści skrzydlatych” z kręgu poety. Podobnie było z historią ocalenia Elżbiety Ficowskiej jako żydowskiego dziecka, które znalazło swoją drugą, nieżydowską matkę. Były to doświadczenia przede wszystkim głęboko osobiste, trzeba jednak zaznaczyć, że Ficowski miał jakąś niezwykłą zdolność przetwarzania ich w fabuły swoiście literackie, nadawania im wymiaru zarówno moralitetu, jak i opowieści niesłychanej, przysparzając im niezwykłej popularności, należącej po części już do sfery kultury popularnej. Dla opisu tego wymiaru aktywności Ficowskiego archiwalia były właściwie źródłem niezastąpionym, jako że gromadziły także świadectwa recepcji, listy do pisarza.

4.

Czynię lejtmotywem refleksji o własnej książce sposób wykorzystywania archiwaliów Ficowskiego, gdyż w miarę pisania tego tekstu uświadamiam sobie, że w istocie one tę książkę przenikały w sposób narastający. Zarysowałem dotąd dwie fazy owego kontaktu z dokumentami. Było to najpierw 
incydentalne sięganie do archiwaliów - w szkicach o historii w poezji, gdzie dokumenty te stanowiły jakby dopowiedzenie, najczęściej w formie przypisu (wspomniany przypadek wiersza Defilada). Wariant drugi to sytuacja, gdy zespół dokumentów, np. grupa zapisów dziennikowych, korespondencja, przesądzał w ogóle o powstaniu rozdziału, inicjował go i stanowił empiryczną podstawę problematyzacji. Nadszedł jednak moment, gdy także sięganie do archiwaliów w tradycyjny sposób przestało wystarczać. Było tak podczas przygotowań do pisania ostatnich trzech części książki o Ficowskim - złożyły się na nie: studium o twórczości piosenkowej, trzy studia o pracach schulzologicznych oraz kończące książkę portrety kilku środowisk bliskich pisarzowi. Ze względu na rozległość owych tematów doszło wówczas do stworzenia właściwie osobnego warsztatu dokumentacyjnego, który w ogóle umożliwił mi ogarnięcie tych zagadnień i zapanowanie nad ogromem świadectw.

Zaplecze archiwalne prac schulzologicznych było niemal niezmierzone. Pani kustosz Ewa Piskurewicz z BUW, która jako pierwsza wstępnie opracowała pośmiertną część schedy po Ficowskim i niezwykle życzliwie odnosiła się do moich kwerend, długo kręciła głową z niedowierzaniem, kiedy pierwszy raz próbowałem wyjaśnić jej zakres swoich prac i to, że interesują mnie schulziana Ficowskiego. Nie wiedziała, że miałem za sobą wieloletnią pracę w zespole Polskiej Bibliografii Literackiej i moje wyposażenie zawodowe obejmowało nie tylko rozumienie dzieła literackiego, ale także zdolność rejestrowania i systematyzacji rozmaitych dokumentów.

W konstruowaniu trzech rozdziałów składających się na część poświęconą badaniom Ficowskiego nad Schulzem szczególnie satysfakcjonujące i w jakimś sensie emocjonujące było dla mnie właśnie owo połączenie pracy interpretacyjnej filologa nad dziełami Ficowskiego z opartym na penetracji archiwów wysiłkiem rekonstrukcji warsztatu pisarza - biografa Schulza. W tym pierwszym nurcie pracy emocjonujące było np. odkrycie, że wykład Schulzowskiej estetyki w Regionach wielkiej herezji ma pewne cechy skrytej programowości Ficowskiego-poety, że estetyka Schulza znalazła swoją kontynuację w poezji Ficowskiego (upodobanie do tropów transformacyjnych, metamorfoz, mitologii), czy też odnalezienie w Okolicach sklepów cynamonowych szeregu rozwiązań narracyjnych właściwych prozie popularnej, zwłaszcza opowieści rekwizytowych (taką nazwę zaproponowałem), które tradycją sięgają XIX-wiecznego obrazka i gazetowych form literackich tamtego czasu.

Rola archiwaliów rosła wówczas, gdy wychodziłem poza owe kategorie poetyki i starałem się ustalić sposób przetworzenia w biografię Schulza 
licznych świadectw uczniów czy znajomych pisarza, zgromadzonych przez Ficowskiego po wojnie. To porównanie umożliwiło opis swoistej strategii beletryzacji, iluzji ciągłości, bliskiej gatunkowi vie romancée - w istocie jednak będącej właśnie pozorem ciągłości - jaką Ficowski realizował w rozdziałach biograficznych Regionów. Owa strategia, swoiście ocalająca jego bohatera, znalazła też wyraz w pozostawieniu w archiwum i nieujawnianiu tych zapisów dotyczących stanów ducha Schulza, sfery jego intymności, które, najogólniej mówiąc, nie nadawały się do kanonu dydaktycznego (zwłaszcza zapisów zawartych w listach Michała Chajesa, Izydora Friedmana, Kazimierza Hoffmanna).

Znajomość autentycznych relacji świadków z archiwum Ficowskiego ułatwiała zrozumienie zawiązywania się konceptów pisarskich na obszarze biografii. Koncept okazywał się skorelowany z wyborem jednych, a przemilczeniem innych świadectw. Był procesem kreowania, zwłaszcza w szkicach z Okolic sklepów cynamonowych, wyrazistych wektorów akcji, emocjonalnej aury, które w archiwalnych źródłach niekoniecznie były na pierwszym planie. Drobny fragment listu, relacji bywał dla Ficowskiego zalążkiem poetyckiego moralitetu, retorycznemu wyostrzeniu ulegała tendencja czasem śladowo tylko obecna w sekwencji dokumentów. Szalenie interesujące były także archiwalne świadectwa oddziaływania figur biograficznych Ficowskiego na czytelników, zgoła ich performatywnego potencjału, np. listy kilku czytelników informujące o rozpoczęciu poszukiwań Mesjasza, pisane krótko po publikacji szkicu Ficowskiego na temat tej zaginionej powieści Schulza.

W przypadku przygotowywania rozdziałów o Ficowskim schulzologu warunkiem wiarygodnych konstatacji było przejrzenie całego archiwum i zarazem przeprowadzenie rejestracji listów (poprzez kartoteki i wykazy), zbudowanie profilów najważniejszych korespondentów, świadków życia Schulza, jego recepcji. Ficowski zresztą w ogóle kontaktował się z ludźmi z dużą intensywnością. Liczni jego wieloletni zagraniczni korespondenci, np. Rafael Scharf, Natan Gross, Leon Fries, Shalom Lindenbaum, Lucjan Dobroszycki, Simon Schochet, Rachela Auerbach, których listy do Ficowskiego tworzą duże zespoły w Ossolineum i Bibliotece Narodowej, nie byli nawet (może z wyjątkiem Lindenbauma) schulzologami, ale tkwiącymi w nurcie spraw polsko-żydowskich partnerami dialogu, doradcami, niekiedy nieformalnymi agentami.

Budując rozdział o procesie rekonstrukcji biografii Schulza przez Ficowskiego, dysponowałem już notatkami z lektury korespondencji pisarza ze świadkami życia Schulza i „agentami” Sprawy Schulza, grupy obejmującej znacznie ponad sto osób. Notatki te układały się w kształt jakby słownika 
biograficznego, połączonego z „mapą terytoriów zamorskich”, z zapisem kierunków emigracji czy ucieczki, wymykania się opresji, poczynając od przedwojennych jeszcze wyjazdów do Erec Israel (Irena Mitelman), do Ameryki Południowej (Maria Budratzka-Tempele), potem wojennych zsyłek do ZSRR (Albin Kac, Elżbieta Lachowicz), wyjazdów powojennych, najpierw na Ziemie Odzyskane, obejmujących bez różnicy Żydów polskich ocalonych z Zagłady i nie-Żydów (np. adwokaci Izydor Friedman i Michał Chajes z Drohobycza, poeta Marian Jachimowicz z Borysławia), wyjazdów poobozowych (Shalom Lindenbaum), aż po emigrację w różnych fazach PRL-u na Zachód bliższy i dalszy (tu już trudno wymieniać nazwiska, jest ich zbyt wiele). Niewielka część uczniów i znajomych Schulza, przeżywszy wojnę, pozostała w Drohobyczu i także z nimi Ficowski nawiązał kontakt (Krawczyszyn, Schreyer, Klügler i kilku inni). Już same koperty i znaczki tych listów stanowią kolekcję tak barwną, jak markownik bohatera Wiosny Rudolfa.

Problemem w odtworzeniu kręgu partnerów Ficowskiego w czasie rekonstrukcji biografii Schulza były - warto o tym wspomnieć - powojenne zmiany nazwisk przez wiele osób. Tu także ujawniał się dramatyzm czasu Zagłady i działanie tej traumy w czasie późniejszym. Odejście od nazwisk żydowskich, albo przeciwnie, od nazwisk z papierów aryjskich czasu okupacji, dokonywało się w różnym czasie, a wyjazd z Polski bywał tutaj istotną cezurą, często uruchamiał proces powrotu do nazwiska pierwotnego. Tak było np. z uczniami Schulza Edmundem Lewandowskim (Löwenthalem) czy Markiem Szpetem (Spaetem). Jeśli listy tego samego nadawcy do Ficowskiego dzielił okres ponad 10-letni, jak w przypadku listów Lewandowskiego - Löwenthala (32 lata) czy Halickiego - Howarda (14 lat), jeśli zmieniało się w tym czasie nazwisko i adres nadawcy, jego charakter pisma, to korespondencja ta w zbiorze bibliotecznym była $\mathrm{z}$ reguły w dwóch miejscach. W takich wypadkach w kojarzeniu pozornie różnoimiennych listów pomagała mi moja profesja dokumentalisty, nabyta w czasach pracy w PBL intuicja w zakresie rejestracji i systematyzacji materiału, łączenia faktów, nazwisk i adresów bibliograficznych, znajomość innych źródeł.

\section{5.}

Piszę w tej chwili głównie o wątku Ficowskiego-schulzologa w mojej książce, o ogarnianiu przeze mnie jego warsztatu biografa, który był wielką zbiornicą osób, wraz z ich losami, zapisanymi w listach, wielką mapą świata. Ale w istocie jest tak, że każdy obszar fascynacji Ficowskiego generował obszerne 
bloki korespondencji, których poznanie było dla mnie ważne ze względu na problematykę recepcji, tworzenia się kręgów wtajemniczeń i kręgów ludzi tej samej idei czy doświadczenia, na wzorcotwórcze oddziaływanie samego Ficowskiego. Osobne wyspy korespondentów tworzyły listy czytelników Odczytania popiołów, cyklu poetyckiego wydanego drukiem w 1979 roku, a później także docierającego w formie kasety magnetofonowej z autorskim wykonaniem wierszy, niekiedy łatwiej przyswajalnym dla polskich Żydów w Izraelu niż tekst drukowany. Obszerny zbiór listów pochodził też od kolekcjonerów, archiwistów i bibliofilów. Do Ficowskiego pisali ponadto ludzie młodzi, uwiedzeni przez teksty piosenek, historie z kręgu estrady (biografia śpiewającego Roma Michaja Burano), młodzi badacze Schulza, osoby zaciekawione kulturą cygańską i sami Romowie.

I w związku z tym co napisałem powyżej, także w aspekcie moich bibliograficznych doświadczeń, z jakimi wszedłem w pracę nad książką o Ficowskim, muszę powiedzieć rzecz ważną, że dość świadomie w sferze egzemplifikacji posługiwałem się w swojej książce figurą me toni mi i. Intuicyjnie czułem, że najlepiej pozwala to oddawać oddziaływanie literatury, a w przypadku twórczości, aktywności pisarskiej dotykającej doświadczeń kluczowych dla wojennego i powojennego czasu, figura ta pozwala na narrację naukową bardziej przestrzenną, ukazującą obecność w kręgu literatury grup społecznych, ich poruszenia związane z jej oddziaływaniem. W praktyce oznaczało to nasycenie tekstu licznymi fragmentami listów, imionami własnymi, nazwiskami korespondentów, nazwami miejsc. Świadom jestem, że ta swoista narracja egzemplifikacji może niektórych odbiorów niepokoić, wydając się zrazu naruszeniem reguł czy granic naukowego dyskursu. Jej zastosowanie było jednak z mojej strony decyzją świadomą.

6.

Doświadczenie bibliografa i dokumentalisty przydało mi się również w pracy nad piosenkami Ficowskiego. Kluczowe okazały się dwa momenty skupienia nad zespołem tekstów piosenek. Odkrycie metodą alfabetyzacji incipitów, że piosenki zmieniały swoje tytuły, co ukazywało ich zaskakująco nowe wcielenia, proces ich estradowej reaktywacji, także w dokumentacji ZAiKS-u, a po wtóre, odnalezienie szeregu przypadków, kiedy okazywało się, że autorstwo piosenki nie było wcale oczywiste, że czasem ta sama piosenka w różnych cząstkowych spisach autorskich, ale także na kilku różnych egzemplarzach maszynopisowych miała różnych autorów - Jerzego Ficowskiego albo jego 
żonę Elżbietę Bussold (tym panieńskim nazwiskiem Ficowska podpisywała swoje teksty, także niepiosenkowe). Dość zasadniczo poszerzyło to moją wiedzę o funkcjonowaniu piosenki jako gatunku, stworzyło w książce pole do opartych na empirii refleksji wokół piosenki jako formy rządzącej się swoimi prawami, odmiennymi zwłaszcza od reguł poezji, a także dostarczyło materiału do interesujących rozmów z Elżbietą Ficowską.

Skądinąd rozmowy te, rejestrowane dyktafonem, także należy zaliczyć do źródłowego zaplecza książki, na równi z obszerną kartoteką tytułów i incipitów piosenek, która stanowiła swoisty bank informacji o utworach, ich wariantach tekstowych, proweniencji. Kiedy temat piosenek pojawił się na moim horyzoncie, w wyniku znalezienia w depozycie Ficowskiego w BUW teczek maszynopisów utworów, projektowałem tylko studium na temat piosenkowego obrazu czasów PRL, charakterystykę tej swoistej kolekcji realiów, stylów bycia, zespołów wartości, obyczajów, sfery tęsknot zbiorowych, tematów, którą to kolekcję teksty piosenek na swój sposób stanowiły. I tego dotyczyła druga część rozdziału Jerzego Ficowskiego oferta piosenkowa. Jednak rozmowy z Ficowską pozwoliły rozszerzyć projektowane studium o całą sferę funkcjonowania rynku piosenki w PRL, znaczenie ZAiKS-u, relacje Ficowskiego i jego żony z wykonawcami i kompozytorami, starania wokół lansowania piosenki (tu w grę wchodziło nawet zakładanie kapeli cygańskiej). Takie wątki rozmów, jak proces sądowy poety w ZAiKS-ie z Mirą Zimińską-Sygietyńską o prawa autorskie do tekstu piosenki śpiewanej przez zespół Mazowsze, pisanie tekstów na rocznicowe zamówienia wojska, wysokość tantiem, rola tekściarstwa w tworzeniu sobie warunków do uprawiania autentycznej twórczości, ukazywały mi Jerzego Ficowskiego jako wolnego twórcę, który w zadziwiający sposób w warunkach PRL-u, unikając stałych zatrudnień etatowych, zarządzał swoim intelektualnym kapitałem.

\section{7.}

Pisanie książki o Ficowskim obfitowało w różnorodność polonistycznych podejść, sposobów obcowania z przestrzenią tekstową i przestrzenią faktów okołoliterackich. Było obserwacją sposobów osadzania się mitów, rozpoznawaniem retoryk epistolarnych i strategii społecznych, było operowaniem perspektywą archiwisty, socjologa, historyka, nie tylko interpretatora tekstów. Nie mnie oceniać, czy książka współtworzy nową jakość w humanistyce, czy sytuuje się w rozszerzającym się nurcie prac zacierających tradycyjne granice kompetencyjne. Budowanie "gmachu dzieła” twórcy nie było celem tej pracy. 
W znacznie większym stopniu pisanie tej książki było posuwaniem się w nurcie historii, śledzeniem i przedstawianiem procesów konsolidacji wspólnot i odnawiania pamięci, rejestracją, ukazywaniem procesów, którym podlega sam pisarz: stanu presji cenzury i odrzucania jej ograniczeń, wikłania się w psychologiczne zależności i zrzucania ciężaru autorytetów, przemieszczania między niszami twórczości elitarnej i popularnej. W obszarach socjologii chodziło o ukazanie, w oparciu o bogate zbiory epistolarne, społeczności ludzi doświadczonych przez historię i percypującej poezję właśnie poprzez to doświadczenie; poezja w takim ujęciu staje się narzędziem zbiorowej terapii, obudzenia pamięci, nie zaś świątynią, której zawiłe wiązania architektoniczne, rytmy i symetrie opisuje się w procesie interpretacji.

W jakimś więc sensie ten rodzaj pisania o twórcy jest raczej byciem w historii i przesuwaniem się w jej paśmie czasu niż pozostawaniem w obrębie tekstu dzieła, a czytanie tej książki jest, chciałbym by tak było, trwaniem w przebiegach czasu, byciem w przestrzeni dziania się, wkraczaniem w świadectwa i relacje. W ślad za tym także tradycyjna norma objętości książki zostaje przekroczona, szersze pasmo narracji wymagało przestrzeni, czyniąc z opracowania na poły ekran historii. Spotykają się tu teksty i wydarzenia, interwały czasu splatają się z analizowanymi utworami, a w samej konstrukcji książki równie ważny jest tekst główny, co teksty w przypisach, aneksy bibliograficzne, warstwa ilustracyjna. I jeszcze jeden aspekt, chyba oczywisty w świetle tego, co powiedziałem wcześniej. Książka o pisarskich rolach Jerzego Ficowskiego nie miała być dla mnie jedynie portretem Ficowskiego, lecz także stanowić opis świata w pewnym kraju, w pewnym czasie, otwierany kluczem jego pisarstwa, miała odsłaniać tajemnice, lęki nierozpoznane, nieopisane, niedomówione również w kręgu rodziny, których historiografia nie dosięgała językiem swoich deskrypcji. 


\section{Abstract}

\section{Jerzy Kandziora}

THE INSTITUTE OF LITERARY RESEARCH OF THE POLISH ACADEMY OF SCIENCES (WARSAW)

The Book that Did Not Want to Be a Biography: A Self-Commentary

In this article Kandziora comments on his book Poeta $w$ labiryncie historii: Studia o pisarskich rolach Jerzego Ficowskiego [A Poet in the Labyrinth of History: Studies on Jerzy Ficowski's Roles as a Writer]. He examines the fact that literary criticism may falsely be read as a traditional writer's biography when it foregrounds research on the historical and social interactions that arise from the practice of writing in a given genre or on a given topic. Kandziora also discusses the role of archives in the production of his book, especially to reveal Ficowski's figures and concepts of a writer and their influence on readers, evident in the letters they sent him.

\section{Keywords}

Jerzy Ficowski, writer's roles, biography, Julian Tuwim, Papusza, song, Bruno Schulz, writer's archive, prop-centered tale, winged tale 